${ }^{1}$ Liena Sofiana, ${ }^{2}$ Arfiani Nur Khusna 'Program Studi Kesehatan M asyarakat, Universitas Ahmad Dahlan 2Program Studi Teknik Informatika, Universitas Ahmad Dahlan Jalan Prof. DR. Soepomo Sh, Warungboto, U mbulharjo, Yogyakarta 55164 Email: liena.sofiana@ikm.uad.ac.id

\section{Peningkatan Edukasi bagi Lansia Sehat dan Produktif}

The Improvement of Education for H ealthy and Productive Elderly People

https:/ / doi.org/ 10.18196/ bdr.7267

\begin{abstract}
Lack of knowledge of the elderly in maintaining health in facing old age causes many health problems in the elderly. The goal to be achieved in mentoring is that the elderly in the Posyandu Lansia (Integrated Healthcare Center for the Elderly) of the Kauman village of Yogyakarta can improve their health knowledge of the elderly as an effort to live healthily, so as to increase the life expectancy of the healthy and productive elderly people. The end of the mentoring is expected that all elderly participants can find out what is happening to the health of the elderly as an effort to live a healthy life. The material presented in this activity includes knowledge about healthy elderly people, diseases and risk factors that occur in the elderly, as well as nutrition and healthy food for the elderly by using case study methods, consultation for healthy living, and the practice of maintaining physical health. Other activities carried out in increasing knowledge in realizing healthy elderly people are by increasing awareness of the elderly to carry out health checks including blood pressure, blood sugar levels, uric acid, and cholesterol and elderly exercise. The results obtained are knowledge and skills for healthy and productive living procedures for the elderly.

Keywords: Health Education, Knowledge, Healthy Elderly
\end{abstract}

\title{
PENDAHULUAN
}

Peningkatan U mur $\mathrm{H}$ arapan $\mathrm{H}$ idup ( $\mathrm{UHH}$ ) merupakan salah satu indikator keberhasilan pembangunan bidang kesehatan. Sasaran rencana strategi Kementerian Kesehatan tahun 2010-2014 adalah meningkatkan UHH dari 70,7 menjadi 72 tahun. M enurut hasil Susenas tahun 2000, jumlah lansia 14,4 juta jiwa atau 7,18\% dari total jumlah penduduk, sedangkan pada tahun 2010 jumlah lansia sudah mencapai 19 juta jiwa atau sekitar $8,5 \%$ jumlah penduduk. Hal ini menunjukkan peningkatan jumlah lansia dan diproyeksikan akan terus meningkat sehingga diperkirakan pada tahun 2020 akan menjadi 28,8 juta jiwa (Kementerian Kesehatan Republik Indonesia, 2012).

M enurut U ndang-undang Republik Indonesia no 13 tahun 1998 tentang kesejahteraan Ianjut usia pada bab I pasal 1 ayat 2, lansia adalah seseorang yang telah mencapai usia 60 


\section{9}

tahun ke atas. Di masa tua seseorang akan mengalami kemunduran fisik, mental dan sosial secara bertahap (Azizah, 2011). Terjadinya kemunduran tersebut dapat berakibat pada terjadinya permasalahan di masa tua antara lain masalah ekonomi, masalah sosial, masalah kesehatan, dan masalah psikologis.

M asalah ekonomi pada lansia terjadi ketika memasuki masa pensiun atau berhentinya pekerjaan utama aki bat adanya penurunan produktivitas kerja sehingga terjadi penurunan pendapatan yang terkait dengan pemenuhan kebutuhan sehari-hari. M asalah sosial terjadi karena adanya perubahan nilai sosial masyarakat yangmengarah pada tatanan masyarakat individualistik, berpengaruh pada lansia yang menjadi kurang mendapat perhatian sehingga tersisih dari kehidupan masyarakat dan terlantar. M asalah kesehatan di masa tua berhubungan dengan adanya penurunan fungsi fisik sehingga rentan terhadap penyakit. O leh karena itu, diperlukan pemberian layanan kesehatan dari orang-orang di sekelilingnya. Terakhir yaitu masalah psikologis yang dapat berupa kesepian, terasing dari lingkungan, ketidakberdayaan, perasaan tidak berguna, kurang percaya diri, ketergantungan, ketelantaran terutama untuk lansia yang miskin, post power syndrome, dan sebagainya (Suardiman, 2011).

Secara fisik, orang yang telah berusia lansia mengalami penuaan pada keseluruhan bagian tubuh termasuk organ-organ di dalam tubuhnya. M eskipun penuaan tersebut terjadi secara tidak serentak bersama-sama di seluruh bagian tubuh, tetapi diawali pada beberapa bagian tubuhnya seperti penuaan kulit, pelemahan fungsi ginjal, postur tubuh yang membungkuk, kadar gula dalam darah, detak jantung yang tidak normal, dan lain sebagai nya. Percepatan penuaan yang dialami setiap orang yang termasuk ke dalam usia lansia tergantung dari pola hidup yang dijalani orang tersebut semasa hidupnya. Pola hidup tersebut meliputi pola makan, pola tidur, jam kerja efektif, aktivitas yang dijalani tergolong berat atau ringan, olahraga, kadar racun di dalam tubuh yang bersumber dari luar seperti rokok, polusi, dan lain sebagainya (Anna, Chusniatun, dan Rudiyanto, 2017).

Kelompok lanjut usia dipandang sebagai kelompok masyarakat yang berisiko mengalami gangguan kesehatan seperti meningkatnya disabilitas fungsional fisik serta sering punya masalah dalam hal makan. Padahal, meskipun aktivitas menurun sejalan dengan bertambahkan usia, ia tetap membutuhkan asupan zat gizi lengkap, seperti karbohidrat, protein, lemak, vitamin, dan mineral. Ia masih tetap membutuhkan energi untuk menjalankan fungsi fisiologis tubuhnya (Adriani M dan W irjatmadi B, 2012).

Proporsi penduduk lansia yang mengalami keluhan kesehatan di daerah pedesaan relatif lebih tinggi daripada di perkotaan (52,81\% berbanding $51,11 \%)$. Berdasarkan D ata 
Riset Kesehatan Dasar (Riskesdas), prevalensi penyakit pada lanjut usia 55-64 tahun adalah H ipertensi 45,9\%, Penyakit Sendi 45\%, Stroke 33\%, Penyakit A sma 5,6\%, Diabetes $5,5 \%$, Kanker $3,2 \%$, Jantung 3,8\%. Jenis penyakit yang mendominasi tersering diderita kelompok lansia adalah golongan penyakit tidak menular, penyakit kronik dan degeneratif, terutama golongan penyakit kardiovaskular (Kementerian Kesehatan Republik Indonesia, 2012).

Pos Pelayanan Terpadu (Posyandu) Lansia adalah suatu wadah pelayanan kesehatan bersumber daya masyarakat (UKBM) untuk melayani penduduk lansia yang proses pembentukan dan pelaksanaannya dilakukan oleh masyarakat bersama lembaga swadaya masyarakat (LSM ), lintas sektor pemerintah dan nonpemerintah, swasta, organi sasi sosial dan lain-lain. Hal tersebut dilakukan dengan menitikberatkan kepada pelayanan kesehatan sebagai upaya promotif dan preventif. Selain pelayanan kesehatan, Posyandu Lansiajuga memberikan pelayanan sosial agama, pendidikan, keterampilan, olah raga, seni budaya, dan pelayanan lain yang dibutuhkan para lansia dengan tujuan meningkatkan kualitas hidup melalui peningkatan kesehatan dan kesejahteraan. Selain itu, Posyandu Lansia membantu memacu lansia agar dapat beraktivitas dan mengembangkan potensi diri (Kementerian Kesehatan Republik Indonesia, 2014).

Kelompok lansia Wijayakusuma III di Kampung Kauman Yogyakarta merupakan kelompok lansia yang berada di pusat Kota Yogyakarta, maka semua arus informasi dan kehidupan sosial sangat beragam dari yang memiliki perekonomian tinggi dan mewah sampai dengan taraf ekonomi yang rendah. Keluarga dengan taraf kehidupan rendah termasuk pada golongan lansia dengan potensi sakit yang tinggi dan tidak produktif karena lingkungan keluarga yang berpendidikan rendah. Pendidikan yang ren dah diiringi dengan gaya hidup perkotaan dapat membuat lansia untuk hidup konsumtif dengan makan makanan siap saji yang tidak memiliki kandungan gizi seimbang sehingga akan berdampak pada munculnya penyakit degeneratif dan akan menimbulkan lansia yang tidak produktif.

U ntuk mengatasi permasalahan tersebut, dilakukanlah pengabdian masyarakat untuk membantu paralansia memecahkan permasalahan hidupnya supaya tetap sehat dan tampil ceria serta semangat. Bentuk pengabdian yang diberikan berupa: (1) Penyuluhan tentang lansia sehat, penyakit, dan faktor risiko yang terjadi pada lansia, (2) Pemberian materi gizi dan makanan sehat untuk lansia, (3) Pemeriksaan kesehatan meliputi tekanan darah, kadar gula darah, asam urat, dan kolesterol. 


\section{1}

\section{METODE PELAKSANAAN}

Bahan yang digunakan dalam upaya peningkatan pengetahuan dalam mewujudkan lansia sehat adalah file power point tentang lansia sehat, LCD, dan layar proyektor. M etode yang digunakan dalam promosi kesehatan ini adalah metodepenyuluhan dan pemeriksaan kesehatan meliputi tekanan darah, kadar gula darah, asam urat dan kolesterol serta senam lansia, kemudian dilanjutkan dengan tanya jawab serta diskusi.

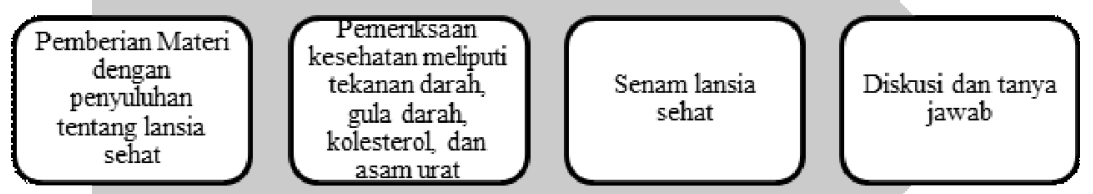

Gambar 1. Alur Pelaksanaan Edukasi Lansia

\section{HASIL DAN PEMBAHASAN}

Kegiatan pengabdian kepada masyarakat ini dilakukan di Posyandu Lansia Kampung Kauman Yogyakarta pada tanggal 17 A pril 2019. Peserta kegiatan adalah masyarakat lansia setempat. Pelaksanaan kegiatan berupa pemberian materi mengenai lansia sehat melalui media promosi kesehatan yaitu penyuluhan dilanjutkan dengan tanya jawab dan diskusi serta dilakukan pemeriksaan kesehatan yaitu tekanan darah, kadar gula darah, asam urat, kolesterol, dan senam sehat. Gambar 2, 3 dan 4 adalah foto-foto kegiatan selama pelaksanaan pengabdian masyarakat.

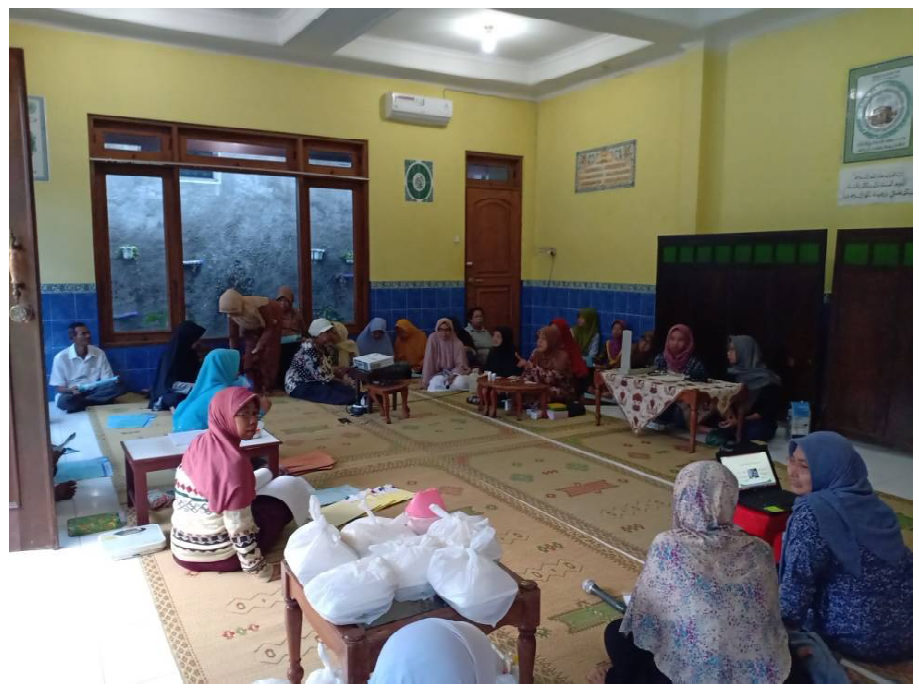

Gambar 2. Pelaksanaan Penyuluhan Mengenai Hipertensi pada Ibu-lbu 


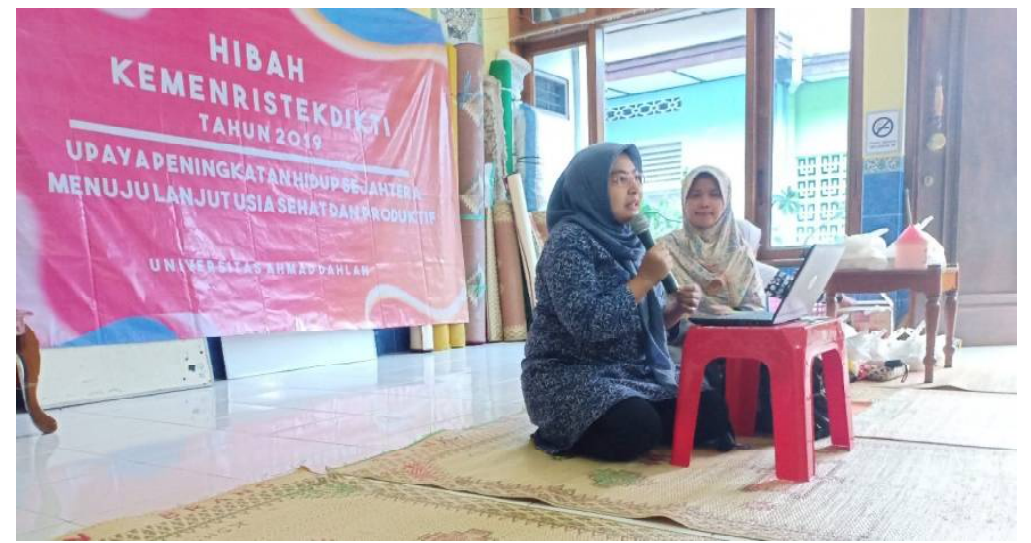

Gambar 3. Pemaparan Materi Gizi dan Makanan Sehat untuk Lansia

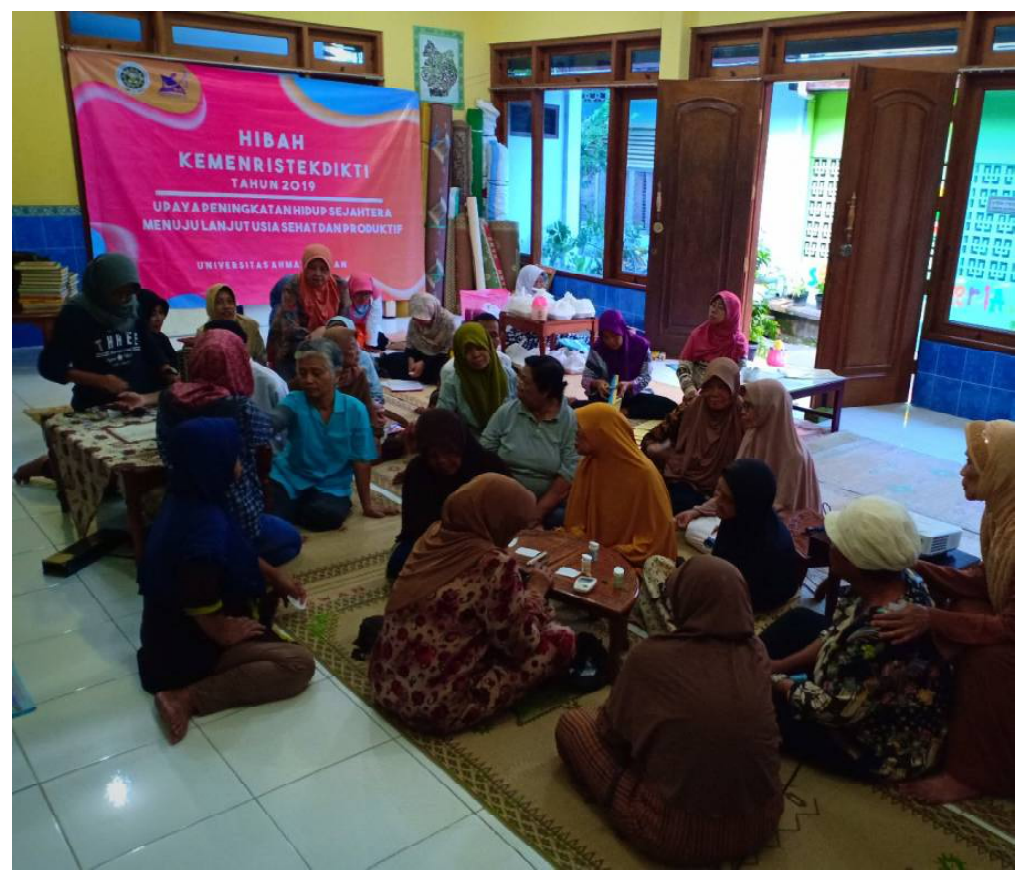

Gambar 4. Pemeriksaan Tekanan Darah, Kadar Gula Darah, Asam Urat, dan Kolesterol

Promosi kesehatan yangdilakukan adalah dengan metode penyuluhan tentanglansia sehat, penyakit dan faktor risiko yang terjadi pada lansia, serta pemberian materi gizi dan makanan sehat untuk lansia. Penyuluhan ini bertujuan untuk memberikan pengetahuan mengenai lansia sehat kepada masyarakat supaya masyarakat dapat mewujudkan lansia sehat. Informasi yang didapatkan dari penyuluhan dapat memberikan pengaruh jangka pendek sehingga dapat menghasilkan perubahan atau peningkatan pengetahuan (Anggreini, 2018). Semakin meningkat pengetahuan masyarakat tentang lansia sehat, para lansia akan terdorong berperilaku lebih baik dalam mewujudkan lansia sehat di masa tua, menghindari konsumsi makanan berkalori tinggi dan menggantinya dengan makanan yangmemiliki asupan gizi yang baik, mencegah masalah kesehatan serta faktor 


\section{3}

risiko yang terjadi pada lansia. Sei ring dengan meningkatnya pen getahuan tentanglansia sehat maka dapat melakukan penatalaksan aan masalah kesehatan yang akan dihadapi demi terwujudnya kesejahteraan di masa tua (W idayani dan Triatma, 2013).

\section{SIM PULAN}

Kaum Lansia di Kampung Kauman memiliki pengetahuan yang baik setelah dilakukannya edukasi mengenai penyakit degeneratif, gizi seimbang, dan dapat mempraktikkan hidup produktif melalui praktik pembuatan jamu untuk kesehatan.

\section{UCAPAN TERIMA KASIH}

1. Kementerian Riset, Teknologi, dan Pendidikan Tinggi Republik Indonesia, sebagai penyumbang dana sehingga kegiatan pengabdian kepada masyarakat ini dapat berjalan dengan lancar dan baik.

2. LPPM U niversitas Ahmad Dahlan yang telah memberikan dukungan dalam segala bentuk untuk terlaksananya kegiatan tersebut.

3. Pemerintah KampungK auman Yogyakarta yang telah memberikan dukungannya dan bantuan selama proses pelaksanaan kegiatan pengabdian kepada masyarakat.

4. Posyandu Lansia Kampung Kauman Yogyakarta yang telah mendukung dan aktif berperan dalam pelaksanaan pengabdian kepada masyarakat.

\section{DAFTAR PUSTAKA}

Adriani M dan Wirjatmadi B (2012) Peranan Gizi Dalam Siklus Kehidupan. Jakarta: Kencana.

Anggreini, D. (2018) 'Pendampingan Cara Menjaga Asupan Gizi Yang Baik dan Kesehatan Pada Lansia di Posyandu Jepun Kabupaten Tulungagung', APLIKASIA: Jurnal Aplikasi IImu-IImu Agama, 18(2), pp. 93-100.

Anna, A. N., Chusniatun and Rudiyanto (2017) 'Kegiatan Penyuluhan Gizi Lansia di Posyandu Aisyiah , Mawar Biru dan Anggrek Berseri Kelurahan Serengen', The 6th University Research Colloquium Universitas Muhammadiyah Magelang, pp. 103-112.

Azizah, L. M. (2011) Keperawatan Lanjut Usia. Yogyakarta: Grha IImu.

Kementerian Kesehatan Republik Indonesia (2012) Pedoman Pelayanan Gizi Lanjut Usia, Pedoman
Pelayanan Gizi Lanjut Usia. J akarta: Direktorat J enderal Bina Gizi dan Kesehatan Ibu dan Anak Kementerian Kesehatan Republik Indonesia.

Kementerian Kesehatan RI (2014) Pusat Data dan Informasi Kementerian Kesehatan RI. Jakarta: Kementerian Kesehatan RI.

Suardiman, S. P. (2011) Psikologi Usia Lanjut. Yogyakarta: Gajah Mada University Press.

Widayani, S. and Triatma, B. (2013) 'Penyuluhan Gizi Dan Kesehatan Serta Pembuatan J us Sehat Untuk Lansia Agar Tetap Tampil Sehat Dan Ceria', Jurnal Abdimas, 17(1), pp. 53-60. 